inland escarpments he mentioned having been old coast lines. It was only aceidentally that sea cliffs had any connexion with the line of strike of the strata, whereas inland cliffs always followed the strike. He thought the phenomena were rather in accordance with a long exposure of the land to sub-aërial influences than with the the loess having been of marine origin. Even in England, in those parts which had long been free from marine action, beds of brick-earth had been formed. He also instanced the plains of Picardy as exhibiting a vast extent of such sub-aërial beds.

Prof. T. Rupert Jones said that though the area treated of by Mr. Kingsmill was too large to have its geology explained merely by reference to rain-wash and valley deposits, whatever his low-level loess might be, the higher accumulations of loamy deposits, stated to be 1000 feet thick at an elevation of 3000 feet, and regarded by Mr. Kingsmill as the quiet water sediments of a great gulf, with the Miocene conglomerates and sandstones of Nanking and elsewhere for its marginal equivalents, appeared to require different explanation. All loess. need not be of sea origin; in oscillations of land marime deposits must be carried up to great heights; and, referring to Mr. H. M. Jenkins's determination of : the marine origin of the loess of Belgium, Prof. Jones thought it highly probable that some at least of that in China may have been similarly formed.

$\mathrm{Mr}$. Hughes. said that the author appeared to have grouped together all the superficial deposits of a vast area without explaining very clearly the grounds upon which he identified those deposits at distant points. He did not prove that what he called the shore deposit was marine, or that it was of the same age as the loam which he described, and which. Mr. Hughes thought, from the description, was far more likely to be sub-aërial.

Mr. Evans and Mr. Etheridge suggested the probability that much of the so-called loess might be derived from higher loamy beds, possibly derived from the decomposition of limestone roeks containing sand and clay, and redeposited by the action of rain.

Edindurgh Geological Socretr.-March 16, 1871. At the fifth ordinary meeting of the Society for this Session held this evening, the following comnunication was read::- "On a new species of Amblypterus, and ather. Fossil Fishes from the shale workings of Pitcorthie, near Crail, in the county of Fife." By Robert Walker; St. Andrew's.

Abstract.-In this paper the anthor commenced by giving a list of the Fossil Fishes he had obtained in a more or less perfect conditiom from the Pitcorthie beds. These embraced the following genera, of: which Eurynotus was the most abundant; there were also numerous scales and teeth of Rhizodus, pieces of Gyrolepis; specimens of Acrodus, Ctenacanthus, Centrodus, Heliodus, Diplodus, Tristychius, Palooniscus, Amblypterus, and some other forms not: yet determined, some of which may ultimately prove to be reptilian. For the new species of Ambly. pterus, the author proposed the name Anconocechmodus, from the peculiar form of the teeth, which along with the external ornamentation of the scales would be sufficient, he considered, to distinguish the species wherever it may be found.

The author gave a full description of the species, which however, without figures, would not be serviceable to publish in detail here.

\title{
CORRESPONTIEINCE.
}

\section{MEAN THICKNESS OF THE SEDIMENTARY ROCKS:}

Sir,-In the Geological Magazine, p. 189, Mr. Poulett Scrope has done me the honour of referring to my paper on the "Mean Thickness of the Sedimentary: Rocks,". and. of pointing out some 
omissions in it. I may mention, however, that the main object of the paper was not so much to determine the thickness of the sedimentary rocks as to direct attention to a method how this might be done. On this subject all hitherto appears to have been little else than mere conjecture. My object was to endeavour to bring the matter out of the regions of mere opinion into that of positive knowledge. But even assuming Mr. Poulett Scrope's conclusions to be perfectly correct, viz., that if we take into account the various sources of sedimentary accumulation at the bottom of the ocean, omitted by me, it will donble the figures in my estimate, and give 5,000 feet instead of 2,500 feet as the mean thickness of the sedimentary rocks, still, this is a very low figure. To know with tolerable certainty that the mean thickness of the sedimentary rocks lies somewhere between 2,000 and 5,000 feet is surely a considerable advance on our previous knowledge in this direction.

But is it probable that the amount of materials supplied by the three agencies referred to by Mr. Poulett Scrope would equal that supplied by sub-aerial denudation?

Take the first, viz., Marine denudation. Suppose the mean height of the coast line of the globe, now being cut down by the action of the sea, to be 25 feet, and the mean rate at which the sea is advancing on the land to be one foot in a century; the amount of denudation thus effected would amount to only $\frac{1}{17}$ that of sub. aerial denudation.' The amount of material supplied by marine denudation would therefore add only $1 \frac{1}{2}$ feet to the thickness of the sedimentary rocks. But supposing the rate of marine denudation to be ten times greater than the above, still we would have an addition of only 15 feet : an amount so insignificant as scarcely worthy of being taken into account in our rough estimate.

Second: Coral-reefs and limestones formed in the sea. From whence come the materials which go to make these formations? Is it not probable that the greater part of these materials are carried down in solution by rivers from the land? The sea, no doubt, has its calcareous springs, but so has the land. But the land has more than springs. Rain water, doubtless, washes into rivers far more calcareous materials than is supplied by springs. And as the country is being denuded, new surfaces are being continually exposed to the action of the water. But not so in regard to the sea; there springs seem to be the only source of supply.

Third: What is the amount of materials supplied by submarine and other volcanoes which deposit their materials directly into the ocean? No one is better qualified to answer this question than Mr. Poulett Scrope himself, and it would be desirable if he would turn his attention to this point, and endeavour to arrive at some estimate, however rough, as to the absolute amount. Without some positive knowledge on this point, one is very apt to be misled when he endeavours to compare the amount of materials supplied by this means with that supplied by sub-aerial or by marine denudation. $W_{\theta}$ have a striking example of this in the case of the comparison of the rate of sub-

I See Phil. Mag. for May, 1868, p. 383. 
aerial with that of marine denudation. Before positive estimates were made in regard to the two rates, no one ever imagined that marine denudation was so trifling in comparison to sub-aerial. Is the amount of materials deposited in the submarine volcanoes equal to that derived from marine denudation? The sea is continually at work, but volcanoes are only now and again in eruption. If the materials supplied by submarine volcanoes be not greater than that by marine denudation, all the three sources which we have been considering put together, must fall far short of supplying an amount of material equal to that supplied by sub-aerial denudation. There is this, however, to be said of volcanoes, viz., the materials which they do produce-lava and trap-rock-resist denudation, and are consequently better preserved than rocks formed out of materials derived from sub-aerial and marine denudation. This, no doubt, is the reason why, in rock sections the traps bear so large a proportion to the sandstones, shales, and other softer rocks. Still further, were it not for the protection afforded by cappings of trap, the sedimentary rocks would be much thinner than they actually are.

Edinburgh.

JAMES CROLI.

THE CRUST OF THE EARTH.

Sir,-With your permission I should like to ask a question or two suggested by one part of Mr. Forbes's very instructive paper in the April number of your Magazine.

Is not the comparison there drawn between the crust of the earth and the shell of an egg likely to produce a somewhat inaccurate impression, which it is as well to avoid, and especially so when, as in the present instance, the illustration to some extent does duty as an argument? In the case of an eggshell, the vault consists of a single piece, so that the form is largely aided by the force of cohesion in supporting a load. The weight is equally distributed by the former, but transverse fracture, crushing of the material and the shearing, or sliding of particle on particle, are, up to a certain extent, prevented by the latter. It is, however, improbable that in the crust of the earth no joints or fissures exist reaching continuously or interruptedly from the top to the bottom. The igneous rocks, as we know them, are so fractured that it is hard to find a mass of many yards in length free from cracks and flaws. Does not the presence of these destroy the analogy between the crust of the earth and an unbroken eggshell? and every one can see how deft a hand would be required to build up the fragments of a broken one, so that it should bear even its own weight. Is it not more correct to liken the crust of the earth to a heavy, but unloaded arch, whose voussiors are constantly sliding on one another, in consequence of the evervarying strain thrown upon the different parts, and the necessity of preserving equilibrium? Considerable up-and-down movement would thus be allowed, evidence of which may be seen in the enormous throws sometimes shown by faults. Cavities, too, might exist underneath the vault without endangering its stability, their size being limited by the ability of the material to resist crushing. 